\title{
Long-term efficacy of surgical ablation of atrial fibrillation in a low-volume centre
}

\author{
Maciej Rachwalik ${ }^{1}$, Dorota Zyśko², Grzegorz Bielicki ${ }^{1,3}$, Marta Obremska $^{1,3}$, Anna Goździk ${ }^{1,3}$, \\ Wojciech Kustrzycki ${ }^{1,3}$
}

${ }^{1}$ Department of Cardiac Surgery, Silesian Piasts University of Medicine in Wroclaw, Poland

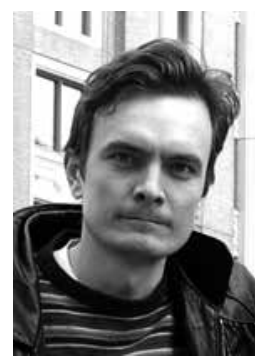

${ }^{2}$ Department of Emergency Medicine, Faculty of Medicine, Silesian Piasts University of Medicine in Wroclaw, Poland

${ }^{3} J a n$ Mikulicz-Radecki University Teaching Hospital, Wroclaw, Poland

Kardiochirurgia i Torakochirurgia Polska 2015; 12 (4): 309-313

\begin{abstract}
Surgical ablation is a recommended procedure for patients with atrial fibrillation (AF) undergoing a cardiac surgery operation. However, the procedure is associated with significant risk of late recurrence of AF. The aim of the study was to assess the long-term efficacy of the procedure with respect to the comorbidities. The study group consisted of 22 patients: 9 women and 13 men, who underwent surgical AF ablation in the 2008-2013 period. The patients were interviewed by telephone and were asked to send their recently performed 12-lead electrocardiography (ECG). The semi-structured interview consisted of 25 items regarding the history of AF, concomitant comorbidities, lifelong syncopal history, smoking, family history of premature cardiovascular diseases, and current medical treatment. Furthermore, the Epworth test was performed to measure the daytime sleepiness, which in turn is related to the presence of obstructive sleep apnoea. On the basis of the obtained data, the $\mathrm{CHADS}_{2}$, and Epworth scale scores were calculated for each patient.

As a result of the study six patients (27\%) had sinus rhythm or paced dual chamber rhythm, and 16 patients had atrial fibrillation. The multivariate analysis revealed that Epworth scale scoring > 9, $\mathrm{CHADS}_{2}$ score $>0$, and persistent type of AF were related to poor outcome of surgical ablation procedure. In conclusion, patients with AF treated with surgical ablation have similar prognosis of sinus rhythm maintenance to those treated with radiofrequency ablation. Moreover, the same predisposing factors play a significant role in AF recurrence both in surgical patients and in patients treated with radiofrequency ablation.
\end{abstract}

Key words: $C A B G$, atrial fibrillation, ablation.

\section{Streszczenie}

Ablacja chirurgiczna to zabieg rekomendowany dla pacjentów z migotaniem przedsionków (atrial fibrillation - AF), którzy poddawani są operacjom kardiochirurgicznym. Zabieg ten jest jednak związany z istotnym ryzykiem późnych nawrotów AF. Celem badania była ocena długoterminowej skuteczności zabiegu w odniesieniu do chorób towarzyszących. W skład grupy badanej weszło 22 pacjentów (9 kobiet i 13 mężczyzn), którzy przeszli chirurgiczną ablację AF w latach 2008-2013. Z pacjentami przeprowadzono wywiady przez telefon i poproszono ich o przesłanie wyników wykonanych niedawno badań 12-odprowadzeniowego EKG. Częściowo ustrukturyzowany wywiad składał się z 25 pytań dotyczących historii AF, historii omdleń z całego życia, przedwczesnego występowania chorób sercowo-naczyniowych w rodzinie oraz przechodzonej obecnie terapii. Ponadto przeprowadzono kwestionariusz Epworth, aby zmierzyć senność pacjentów w ciągu dnia, która związana jest z występowaniem obturacyjnego bezdechu sennego. Na podstawie uzyskanych danych obliczono wyniki skal $\mathrm{CHADS}_{2}$ oraz Epworth dla każdego z pacjentów.

Zgodnie z wynikami badania rytm zatokowy lub prawidłowy rytm stymulowany dwukomorowo występował u 6 pacjentów (27\%), a migotanie przedsionków - u 16 pacjentów. Analiza wielowymiarowa wykazała, że wyniki skali Epworth > 9, wyniki $\mathrm{CHADS}_{2}>0$ oraz przetrwały typ AF były związane ze złymi wynikami ablacji chirurgicznej. Podsumowując, rokowanie dla pacjentów z AF w zakresie utrzymania rytmu zatokowego wygląda podobnie w przypadku pacjentów leczonych ablacją chirurgiczną i pacjentów poddawanych ablacji częstotliwościami radiowymi. Ponadto, zarówno u pacjentów leczonych chirurgicznie, jak i u pacjentów leczonych ablacją częstotliwościami radiowymi istotną rolę $\mathrm{W}$ nawracaniu AF odgrywają te same czynniki predysponujące.

Słowa kluczowe: $C A B G$, migotanie przedsionków, ablacja. 


\section{Introduction}

Surgical atrial fibrillation (AF) ablation concomitant to other heart operations is a standard procedure for AF patients undergoing a cardiac surgery operation [1]. Similarly to transcatheter ablation, the surgical one is associated with a significant risk of late recurrence of AF [1-7]. The dominant mechanism of AF relapse after ablation is electrical reconnection of the pulmonary veins. However, ongoing electrical and structural remodelling of the atria as a result of aging, heart failure, inflammation, and other comorbidities such as diabetes may play an important role in the AF recurrences [3]. Moreover, the procedure is related to the risk of complications or even death. Therefore, studies evaluating the risk factors for the recurrence of AF after surgical ablation are necessary to determine the indications for surgical ablation of AF.

The aim of the study was to assess the long-term efficacy of surgical ablation of AF concomitant to other heart operations with respect to the comorbidities.

\section{Material and methods}

The study was undertaken in a low-volume centre in which we perform around 450 cases per year. In our institu-

Tab. I. Clinical characteristics of the studied groups

\begin{tabular}{|c|c|c|c|}
\hline Factor & Group $1, n=6$ & Group $2, n=16$ & $p$ \\
\hline Age (years) & $67.8 \pm 7.1$ & $66.9 \pm 10.2$ & NS \\
\hline Height $(\mathrm{cm})$ & $166.8 \pm 7.9$ & $168.2 \pm 9.3$ & NS \\
\hline Weight (kg) & $79.3 \pm 14.2$ & $84.5 \pm 14.8$ & NS \\
\hline Male (\%) & $2(33.3)$ & $(43.8)$ & NS \\
\hline Persistent AF (\%) & $2(33.3)$ & $12(81.2)$ & NS \\
\hline $\begin{array}{l}\text { Myocardial } \\
\text { infarction (\%) }\end{array}$ & $0(0)$ & $4(25.0)$ & NS \\
\hline $\mathrm{CHADS}_{2}$ (points) & $1.0 \pm 1.26$ & $1.19 \pm 1.0$ & NS \\
\hline $\mathrm{CHADS}_{2}>0$ (points) & $14(87.5)$ & $3(50.0)$ & NS \\
\hline Thyroid (\%) & $0(0)$ & $5(26.7)$ & NS \\
\hline Current smoker (\%) & $0(0)$ & $1(6.7)$ & NS \\
\hline Ever smoker (\%) & $5(83.3)$ & $13(86.7)$ & NS \\
\hline $\begin{array}{l}\text { Family history of } \\
\text { premature cardiova- } \\
\text { scular disease (\%) }\end{array}$ & $3(18.8)$ & $0(0)$ & NS \\
\hline Snoring (\%) & $3(50.0)$ & $6(40.0)$ & NS \\
\hline $\begin{array}{l}\text { Epworth score } \\
\text { (points) }\end{array}$ & $6.8 \pm 4.3$ & $7.9 \pm 4.4$ & NS \\
\hline $\begin{array}{l}\text { Epworth score }>9 \\
(\%)\end{array}$ & $(46.7)$ & $1(16.7)$ & NS \\
\hline $\begin{array}{l}\text { Operation duration } \\
\text { (min.) }\end{array}$ & $227.5 \pm 47.7$ & $235.4 \pm 56.5$ & NS \\
\hline $\begin{array}{l}\text { Exrtracorporeal circu- } \\
\text { lation time (min.) }\end{array}$ & $142.8 \pm 19.7$ & $127.4 \pm 62.9$ & NS \\
\hline $\begin{array}{l}\text { Cross clamp time } \\
\text { (min.) }\end{array}$ & $77.5 \pm 27.7$ & $76.6 \pm 44.5$ & NS \\
\hline
\end{tabular}

tion ablation procedures have been performed if needed since 2004, depending on the type of surgery. The most common operations during which the ablation procedures performed were mitral regurgitation (Table I) operations. Ablation and the following operations are carried out by two cardiac surgeons. In most cases the operations are carried out at moderate hypothermia $\left(32^{\circ} \mathrm{C}\right)$. Each time, ablation is performed as the first part of the surgical procedure using an Estech COBRA ${ }^{\circledR}$ Electrosurgical Unit with monopolar temperature-controlled radiofrequency multi-electrode Surgical Probe ${ }^{\mathrm{TM}}$. The COBRA System automatically adjusts power output to achieve and maintain safe and effective target temperature. The generator receives feedback from each electrode fifty times per second to ensure proper temperature levels. The lesion set is the same for all patients and is intended to be performed prior to the valve or coronary artery bypass graft (CABG) procedure after placing the patient on cardiopulmonary bypass (CPB) and arresting the heart. Protection is achieved using a crystalline cardioplegia (PLEGISOL) usually administered through the line to the aortic root. The left atrium is opened below septum basically. It includes pulmonary veins (PV) ablation (left-sided separately and right-sided PV pairs), left atrial appendage (LAA), and three other lesions, namely an interconnecting lesion between PV pairs, connecting lesion from the mitral annulus in PV, and a lesion from the left upper pulmonary vein to the rim of the LAA. The lesion lines are not planned to be assessed for conduction block so as not to prolong the surgical procedure. The left atrium is closed with continuous prolene suture 3-0.

Postoperative care is identical for both groups. Unless contraindicated, all patients receive antiarrhythmic drugs (AADs) postoperatively on the day of surgery: amiodarone as the first choice, or propafenone or sotalol as the second choice. All patients are put on warfarin with a target international normalised ratio of 2 to 2.5. After surgery and extubation, patients are treated with LBA ( $\beta$-blockers) (Bisoprolol, Metoprolol). Amiodarone is used only selectively in the early postoperative period for recurrent atrial arrhythmias. The case is considered to be a success if patient has a normal sinus or pacing rhythm and is free from AF and class III anti-arrhythmic drugs at 12 months. In our group, the completion of the follow-up protocol was $40 \%$. The study was approved by the local Ethics Committee at the Medical University of Wroclaw, Poland.

The study group consisted of 42 patients who underwent ablation in 2008-2013 as a concomitant procedure to another surgical operation. We then excluded only those patients who did not participate in a survey after surgery or did not send a follow-up electrocardiography (ECG) at least one year afterwards. Finally, the group of patients consisted of 22 patients: 9 women and 13 men, aged \pm 9.3 years.

The patients were interviewed by telephone and asked to send their recently performed 12-lead ECG.

Semi-structured interview consisted of 25 items regarding the history of AF, concomitant comorbidities, lifelong syncopal history, smoking, family history of premature car- 
diovascular diseases, and current medical treatment. Furthermore, the Epworth test was performed to measure the daytime sleepiness, which in turn is related to the presence of obstructive sleep apnoea.

On the basis of the obtained data the $\mathrm{CHADS}_{2}$ [3] and Epworth scale [8] scores were calculated for each patient.

\section{Statistical analysis}

The variables are presented as mean and standard deviation, median and interquartile range, and numbers and frequencies when appropriate. They were compared with Student $t$ test, Mann Whitney $U$ test, and $\chi^{2}$ test.

The multivariate analysis was performed using classification and regression trees (CART) analysis. The method was described in details elsewhere [9]. Briefly, CART analysis is a non-parametric, non-linear method based on binary partitioning of the studied population into subgroups, which are formed by examining each possible cut point of each variable to identify the cut points that resulted in the maximum discrimination between subgroups of patients with respect to the probability of an assessed outcome.

Classification and regression trees generates a classification rule that is visualised as a "classification-tree", and its results are presented as a graph. The graph consists of rectangles. In the right corner is the number that corresponds to the assessed outcome that is more prevalent in that group.

The dependent variables that are used for the "classification tree" formation are those related to the determined outcomes.

$P<0.05$ was regarded as significant.

\section{Results}

\section{Study group}

A total of 21 patients provided information by phone and sent the 12 -lead ECG by mail. The $22^{\text {nd }}$ patient included into the study, who died two years after surgery, had a known AF relapse, but the questionnaire was not filled out and only limited information regarding some of the questionnaire items were available.

\section{The electrocardiography findings}

A group of six patients had sinus rhythm or paced dual chamber rhythm (Group 1), and 16 patients had atrial fibrillation (Group 2). As mentioned earlier, one patient died but AF relapse was found in the ECG taken before the death.

Clinical characteristics of the studied groups are presented in Table I.

\section{Multivariate analysis}

The multivariate analysis revealed that Epworth scale scoring $>9, \mathrm{CHADS}_{2}$ score $>0$, and persistent type of $\mathrm{AF}$ were related to poor outcome of surgical ablation procedure (Fig. 1).

\section{Discussion}

The first finding of the study was that the outcome of surgical ablation could be predicted by the presence of clinical factors like persistent type of atrial fibrillation and parameters used on the $\mathrm{CHADS}_{2}$ scale $[3,10]$. It is well known that these factors are also related to $A F$ recurrence after transcatheter ablation $[11,12]$. This result highlights the role of structural remodelling of the atrium in the prognosis of

Classification tree for atrial fibrillation relapse

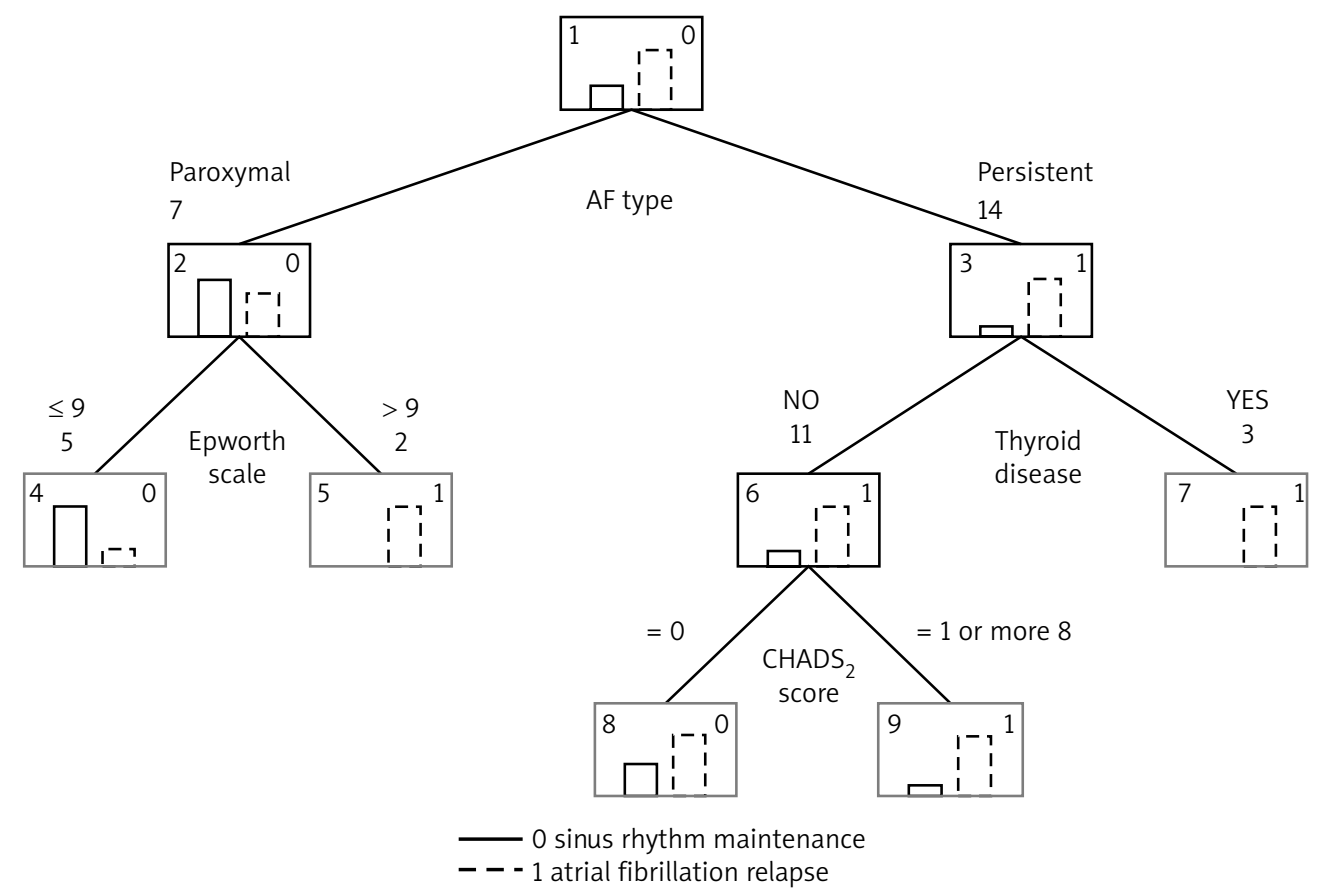

Fig. 1. Clinical factors related to atrial fibrillation (AF) relapse. Global CV $=0.70$, global CV cost 0.30 , SD CV cost 0.11 
patients with AF treated with surgical ablation concomitant to another heart operation. The importance of clinical factors in predicting the long-term outcome of the ablation procedure was confirmed in the study. Unfortunately, the small size of the study group did not allow us to assess the importance of each clinical factor separately.

The results are consistent with the studies of other authors. Zheng et al. reported that duration of AF > 24 months before procedure, early recurrence of $A F$, and left atrial diameter also predicted long-term recurrences of AF [13].

In the study group the sinus rhythm maintenance was $27 \%$, which was lower than in other studies on the longterm outcomes of radiofrequency surgical ablation of AF. Other authors reported better results: Doukas et al. reported a 12 -month success rate of $45 \%$ [4]. The success rate in terms of sinus rhythm stability in patients with atrial fibrillation treated with surgical ablation was twice as high or even higher in other studies, especially when modern alternative energy sources are used [1, 7, 14, 15]. However, the results are significantly worse in patients with multiple adverse risk factors [16]. Moreover, the results are related to the extent of the ablation and the technical equipment [14]. The clinical characteristics of the treated patients are related to outcomes, so the differences in clinical parameters between groups may account for differences in outcomes [12] providing worse outcome in patients after myocardial infarction. The learning curve may account for the differences in obtained results. Another reason may be the methodology of ablation procedure. Biatrial ablation compared to left atrial ablation appeared to be more efficacious in achieving sinus rhythm after 12 months, but there was no difference later $[17,18]$.

The poor prognosis in the patients with severe valvular or ischaemic heart disease in terms of sinus rhythm maintenance indicates the necessity of earlier implementation of ablation before there are serious structural changes [19]. Furthermore, studies on the effects of measures aimed to control modifiable factors related to AF relapse are needed. The most promising therapies are those related to treatment of obstructive sleep apnoea. In the study the patients were divided, on the basis of the Epworth scale score, into two groups with either normal ( $<10$ points) or elevated results. Therefore, the presence of obstructive sleep apnoea was not assessed. The most noticeable sign of obstructive sleep apnoea is snoring. In univariate analysis the occurrence of daily snoring or very frequent occurrence of snoring was similar in both groups chosen on the basis of the surgical ablation outcome. However, the self-assessment may yield less accurate results than more objective assessment with the Epworth scale.

\section{Limitations}

The main limitation of the study is the low percentage of patients who responded to the telephone call and sent their 12-lead ECG. Furthermore, the telephone call alone is not the method recommended by the HRS to collect data regarding long-term efficiency of the ablation of atrial fibrillation. Holter monitoring, repeated on a regular basis, should be recorded [1]. Additionally, the presence of sinus rhythm on the ECG does not exclude paroxysmal AF.

The second important limitation of the study is that the results may be not applicable to high-volume centres that apply more technologically advanced ablation electrodes.

The third limitation is that patients who died were excluded from the analysis. Their death could be related to studied factors that might have evolved into acute complications like stroke or myocardial infarction.

\section{Conclusions}

1. The same predisposing factors play a significant role in $A F$ recurrence in surgical patients and in patients treated with radiofrequency ablation.

2. The obtained results are poor, which may partially be related to patients' comorbidities, but the adverse impact of learning curve, low centre volume, and older technical equipment is highly probable.

3. Further studies are needed to assess the importance of the treatment of obturative sleep apnoea in preventing atrial fibrillation relapse.

\section{Disclosure}

Authors report no conflict of interest.

\section{References}

1. Calkins H, Kuck KH, Cappato R, Brugada J, Camm AJ, Chen SA, Crijns HJ, Damiano RJ Jr, Davies DW, DiMarco J, Edgerton J, Ellenbogen K, Ezekowitz MD, Haines DE, Haissaguerre M, Hindricks G, lesaka Y, Jackman W, Jalife J, Jais P, Kalman J, Keane D, Kim YH, Kirchhof P, Klein G, Kottkamp H, Kumagai K, Lindsay BD, Mansour M, Marchlinski FE, McCarthy PM, Mont JL, Morady F, Nademanee K, Nakagawa H, Natale A, Nattel S, Packer DL, Pappone C, Prystowsky E, Raviele A, Reddy V, Ruskin JN, Shemin RJ, Tsao HM, Wilber D. 2012 HRS/EHRA/ECAS Expert Consensus Statement on Catheter and Surgical Ablation of Atrial Fibrillation: recommendations for patient selection, procedural techniques, patient management and followup, definitions, endpoints, and research trial design. Europace 2012; 14: 528-606.

2. Gościniak P, Kowalik I, Sielicki P, Brykczyński M. Predictors of short- and mid-term recurrence of atrial fibrillation after surgical radiofrequency ablation: a six-month transtelephonic electrocardiogram onitoring study. Cardiol J 2013; 20: 499-505.

3. Kornej J, Hindricks G, Kosiuk J, Arya A, Sommer P, Husser D, Rolf S, Richter S, Huo Y, Piorkowski C, Bollmann A. Comparison of CHADS2, R2CHADS2, and CHA2DS2-VASC scores for the prediction of rhythm outcomes after catheter ablation of atrial fibrillation: the Leipzig Heart Center AF Ablation Registry. Circ Arrhythm Electrophysiol 2014; 7: 281-287.

4. Doukas G, Samani NJ, Alexiou C, Oc M, Chin DT, Stafford PG, Ng LL, Spyt TJ. Left atrial radiofrequency ablation during mitral valve surgery for continuous atrial fibrillation: a randomized controlled trial. JAMA 2005; 294 : 2323-2329.

5. Cox JL, Canavan TE, Schuessler RB, Cain ME, Lindsay BD, Stone C, Smith PK, Corr PB, Boineau JP. The surgical treatment of atrial fibrillation. II. Intraoperative electrophysiologic mapping and description of the electrophysiologic basis of atrial flutter and atrial fibrillation. J Thorac Cardiovasc Surg 1991; 101: 406-426.

6. Khargi K, Hutten BA, Lemke B, Deneke T. Surgical treatment of atrial fibrillation; a systematic review. Eur J Cardiothorac Surg 2005; 27: 258-265.

7. Deneke T, Khargi K, Voss D, Lemke B, Lawo T, Laczkovics A, Mügge A, Bösche LI, Lindstaedt M, Germing A, Horlitz M, Grewe PH, Fritz M. Long-term sinus rhythm stability after intraoperative ablation of permanent atrial fibrillation. Pacing Clin Electrophysiol 2009; 32: 653-659. 
8. Johns MW. A new method for measuring daytime sleepiness: the Epworth sleepiness scale. Sleep 1991; 14: 540-545.

9. Rudnicki J, Zyśko D, Kozłowski D, Kuliczkowski W, Koźluk E, Lelonek M, Piątkowska A, Gajek J, Negrusz-Kawecka M, Agrawal AK. The choice of surgical specialization by medical students and their syncopal history. PLoS One 2013; 8: e55236.

10. Chao TF, Cheng CC, Lin WS, Tsao HM, Lin YJ, Chang SL, Lo LW, Hu YF, Tuan TC, Suenari K, Li CH, Liu SH, Hartono B, Wu TJ, Chen SA. Associations among the $\mathrm{CHADS}(2)$ score, atrial substrate properties, and outcome of catheter ablation in patients with paroxysmal atrial fibrillation. Heart Rhythm 2011; 8: 1155-1159.

11. Koźluk E, Zyśko D, Piatkowska A, Lodziński P, Kiliszek M, Małkowska M, Balsam P, Rodkiewicz D, Żukowska M, Opolski G. Clinical and anatomical models of atrial fibrillation ablation in patients with common pulmonary vein trunk - preliminary report. Pol Przegl Kardiol 2013; 15: 241-249.

12. Osmancik P, Budera P, Straka Z, Widimsky P. Predictors of complete arrhythmia free survival in patients undergoing surgical ablation for atrial fibrillation. PRAGUE-12 randomized study sub-analysis. Int J Cardiol 2014; 172: 419-422.

13. Zheng S, Zeng Y, Li Y, Han J, Zhang H, Meng X. Active ganglionated plexi is a predictor of atrial fibrillation recurrence after minimally invasive surgical ablation. J Card Surg 2014; 29: 279-285.
14. Damiano RJ Jr. Why do most patients with atrial fibrillation referred for oth er cardiac surgery not receive concomitant ablation? A plea for a more aggressive surgical approach. J Thorac Cardiovasc Surg 2014; 148: 3034-3035.

15. Bartczak K, Banach M, Walczak A, Jander S, Jaszewski R. Surgical ablation using the Estech Cobra system in patients with permanent atrial fibrillation treated due to mitral valve disease. A preliminary study. Kardiochir Torakochir Pol 2008; 5: 15-18.

16. Pinho-Gomes AC, Amorim MJ, Oliveira SM, Azevedo L, Almeida J, Maciel MJ, Pinho P, Leite-Moreira AF. Concomitant unipolar radiofrequency ablation of nonparoxysmal atrial fibrillation in rheumatic and degenerative valve disease. J Card Surg 2015; 30: 117-123.

17. Phan K, Xie A, Tsai YC, Kumar N, La Meir M, Yan TD. Biatrial ablation vs. left atrial concomitant surgical ablation for treatment of atrial fibrillation: a meta-analysis. Europace 2015; 17: 38-47.

18. Huang WZ, Wu YM, Ye HY, Jiang HM. Comparison of the outcomes of monopolar and bipolar radiofrequency ablation in surgical treatment of atrial fibrillation. Chin Med Sci J 2014; 29: 28-32.

19. Damiano RJ Jr, Badhwar V, Acker MA, Veeragandham RS, Kress DC, Robertson JO, Sundt TM. The CURE-AF trial: a prospective, multicenter trial of irrigated radiofrequency ablation for the treatment of persistent atrial fibrillation during concomitant cardiac surgery. Heart Rhythm 2014; 11: 39-45. 